\title{
深層学習による海底地形図超解像の手法比較と検証
}

\author{
日高 弥子 ${ }^{1)} \cdot$ 松岡 大祐 $^{* 2)} \cdot$ 桑谷 立 $^{3)} \cdot$ 金子 純二 ${ }^{4)} \cdot$ 笠谷 貴史 $^{5)} \cdot$ \\ 木戸 ゆかり ${ }^{6)} \cdot$ 石川 洋一 ${ }^{7)} \cdot$ 木川 栄一 ${ }^{8)}$
}

\section{Super-resolution for Ocean Bathymetric Maps Using Deep Learning Approaches : A Comparison and Validation}

\author{
Mitsuko HIDAKA ${ }^{1)}$, Daisuke MATSUOKA ${ }^{* 2)}$, Tatsu KUWATANI ${ }^{3)}$, Junji KANEKO ${ }^{4)}$, \\ Takafumi KASAYA ${ }^{5)}$, Yukari KIDO ${ }^{6)}$, Yoichi ISHIKAWA ${ }^{7)}$ and Eiichi KIKAWA ${ }^{8)}$
}

\begin{abstract}
Ocean bathymetric maps are extremely important, providing fundamental information for a variety of research fields, and high-resolution is critical for many applications. More than $80 \%$ of ocean bathymetry remains un-mapped by acoustic survey. Much effort is now being expended to fill in the un-mapped area in high-resolution and over a global scale, and the present study attempted to contribute to that effort through enabling the production of high-resolution bathymetric maps from lower-resolution data. We have trialed super-resolution techniques for ocean bathymetry using deep learning approaches and reveal the potency of these methods. Five deep-learning super-resolution architectures, which were already recognized as state-of-the-art methods in natural-image super-resolution tasks, were applied to the task to generate from a $100 \mathrm{~m}$-mesh grid, a $50 \mathrm{~m}$-mesh grid ocean bathymetric map. The results suggest that each method has strengths and weaknesses, depending on the water depth gradient in the ocean bathymetric map area, and we conclude that it may be better to use different methods depending on the area of the maps for which the higher resolution is desired. Key words : Ocean-bathymetry, Super-resolution, Machine learning, Deep convolutional neural network, Image processing
\end{abstract}

\section{1. はじめに}

詳細な海底地形情報は，地形学的観点はもとより海洋物 理学・防災・資源管理・生物地理学など多様な分野におい て重要な基本情報である。しかし，地球表面の約 $71 \%$ を 占める全海洋底のうち，音響調査などにより取得された海 底地形情報は $20 \%$ に満たない。全球的に詳細な海底地形 図をどのように集めるか，また，その不足をどう補うか は, 世界共通の課題となっている。 この課題解決に取り 組むため，国内外において「Nippon Foundation - GEBCO SEABED2030 Project (SEABED2030)」(Mayer et al., 2018) や「DeSETプロジェクト」(DeSET, 2020) などの大型プロ
ジェクトが現在進行中である。海洋研究開発機構（以下, JAMSTEC）は，長年JAMSTECで取得された海底地形図を 有効活用し，「SEABED2030」へのデー夕提供だけでなく， 海底地形情報の不足を補うための先進的な技術開発に取 り組むため，2019年10月に独自の分野横断的新研究プロ グラム「数理海底地形科学」を始動した（木戸，2020）.

低解像度の海底地形図から高解像度の海底地形図を生 成する技術は，船舶による網羅的で且つ詳細な音響調査 が困難である場合，補足的な手段として期待できる。こ れには，画像の入力信号の解像度を高めて高解像度の出 力信号を作る画像処理手法の超解像と呼ばれる技術が応

2020年 11 月 6 日受付２021年1月 22 日受理Ｒeceived: 6 November 2020; Accepted: 22 January 2021

1）国立研究開発法人海洋研究開発機構 付加価值情報創生部門 ₹ 236-0001 神奈川県横浜市金沢区昭和町. 3173-25. Research Institute for Value-Added-Information Generation (VAiG), Japan Agency for Marine-Earth Science and Technology (JAMSTEC), 3173-25 Showa-machi, Kanazawa-ku, Yokohama, Kanagawa 236-0001, Japan. E-mail: mitsukou@jamstec.go.jp

*2）国立研究開発法人海洋研究開発機構 付加価值情報創生部門. Research Institute for Value-Added-Information Generation (VAiG), Japan Agency for Marine-Earth Science and Technology (JAMSTEC). E-mail: daisuke@ jamstec.go.jp

3)-8）文末の脚注に示す. See the footnote on the last page.

*は代表者. * indicates the representative author. 
用でき，この場合，画像の色情報の代わりに，小領域に 切り出した水深のグリッドデー夕を用いる。超解像技術 には, 同じ対象に対する複数枚の低解像度画像から高解 像度画像を再構成するマルチフレーム超解像と，1枚の 低解像度画像から高解像度画像を再構成するシングルフ レーム超解像がある。これまで, 観測の簡便性から，1枚 の低解像度画像から高解像度画像を推定することができ るシングルフレーム超解像が特に活発に研究されてきた。 画像の拡大に打ける最もシンプルな手法は, Bilinear法や Bicubic 法などの数学的補間を用いたアプローチであるが, これらは高周波成分の補間において性能が劣化するなど の課題があった，そこで現在，主流となっている手法は， スパースコーディング (e.g. Yang et al., 2008, 2010) や後 述の深層学習（ディープラーニング）のように, 低解像度 画像と高解像度画像のペアからその対応関係を学習する, 学習型のアプローチである.

海底地形図, あるいは陸域地形デー夕の超解像に打い ても，スプラインなどの数学的補間法 (e.g. Briggs, 1974; 井上, 1985; 野々垣ほか, 2008; Nock et al., 2019) やフラ クタル（横矢ほか, 1987), 地球統計学 (e.g. Deutsch and Journel, 1998; Chilès and Delfiner, 2012) に基づく手法から, ニューラルネットワーク (e.g. Koike et al., 2002; Koike and Matsuda, 2003)，それを高度化した深層学習を用いた手法 （e.g. 伊藤, 2019; Sonogashira et al., 2020）まで様々な手法 が提案されている。,中でも，深層学習による手法は，その 原理がHinton and Salakhutdinov（2006）によって確立され て以来，急速に発展してきた技術である，スパースコー ディングが少数の重要な特徵量によって超解像を行うのに 対し, 深層学習を用いた超解像は, 多層かつ多量の特徵抽 出フィルタの組み合わせによってデー夕に含まれる複雑な 特徵抽出が可能である。深層学習は, 海底地形図の超解像 においても従来の補間手法を凌駕するアプローチとして注 目されている。深層学習による海底地形図の超解像は, 近 年いくつかの研究例が報告されているものの，始まったば かりであり，各手法に打ける有効性などについて比較した 例は少ない

本研究では, 異なる複数の深層学習手法を海底地形図 の超解像に適用することで得られる結果やその有効性に ついて比較することを目的とした，マルチビーム測深機 (MBES) で計測された観測データを元に作成された $100 \mathrm{~m}$ グリッドの格子データと, それに対応する 2 倍の解像度で ある50 m グリッドの格子デー夕に5つの深層学習超解像 アーキテクチャを適用し, 海底地形図の超解像を試みた。 各アーキテクチャで得られた結果とBicubic 法による補間 の結果を, 複数の異なる指標で評価し, 得られた超解像結 果について有効性を検証した。

\section{2. データと方法}

以下に本研究で用いたデー夕, 5つの深層学習超解像 アーキテクチャおよび3つの評価指標について説明する.

\section{2-1. データ}

本研究に扔ける, 深層学習による超解像では, 高解像度 化したい低解像度格子データ（LR: Low-Resolution）に対応 する標的解像度の格子デー夕（HR: High-Resolution）のペ アを学習データとして用いる。具体的には, 複数機種のマ ルチビーム測深機によって得られた中部沖縄トラフの水 深の点群デー夕を統合・補正処理扮よび格子計算処理し, それぞれ $50 \mathrm{~m}$ と $100 \mathrm{~m}$ 間隔のメッシュグリッドにしたも のである（笠谷ほか，2020）。それぞれの格子データから， HR（50 mメッシュグリッド）で $64 \times 64$ グリッド，それに 対応するLR（100 mメッシュグリッド）の $32 \times 32$ グリッ ドを切り出し, 学習データセットを作成した. HRは 8 グ リッド，対応するLRでは 4 グリッド毎にスライドし，少 しずつ領域をずらすことでデータの水増しを行った，これ により13723ペアの画像セットを作成し, Hold-out法 (利 用可能なデータセットの全量を学習とテストデータに分け る）により 8 割を学習データ，2割をテストデータにラン ダムに分割した。対象海域の海底水深の分布は第 1 図 (a) に示し，それぞれ学習とテストに用いた領域の詳細を第 1 図(b)に示した。
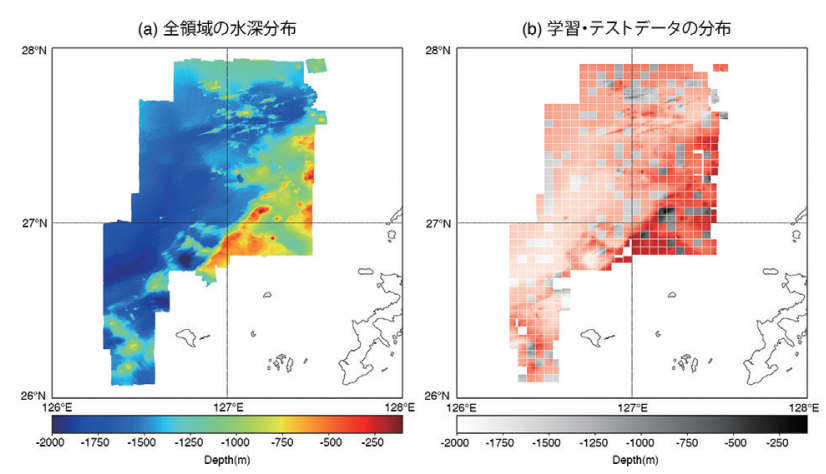

第1図 モデルのトレーニングとテストに用いた海底地形データの 分布図. (a) 本研究に用いた海底地形の全領域に扔ける水 深分布。(b) 学習に用いた領域とテストに用いた領域の分 布図. 赤 $\rightarrow$ 白：学習に使用した領域，黒 $\rightarrow$ 白：テスト（精 度検証）に使用した領域。

\section{2-2. 超解像アーキテクチャ}

深層学習は, 多層かつ多量の特徵抽出フィル夕の組み 合わせを実装することで，デー夕に含まれる複雑な特徵 抽出を可能にする機械学習の一手法である。，その中でも， 画像認識に用いられる疊み込みニューラルネットワーク (CNN) (Lecun et al., 1998; Krizhevsky et al., 2012) や敵対的 生成ネットワーク（GAN）(Goodfellow et al., 2014）などの アーキテクチヤは, state-of-the-art な手法として画像分類 · 物体検出などの分野で極めて高い評価を得てきた。低解像 
度画像の高解像度化を行う超解像においても，これらを基 本構造とした様々なアーキテクチャが提案されている。本 研究では, これまでに提案された深層学習超解像アーキテ クチャの中から, 比較的シンプルな CNNである $\mathrm{SRCNN}$, FSRCNN と ESPCN，2つの異なるネットワークが相互に学 習し合う複雑なネットワークの GANを用いたSRGAN と ESRGANの計5つの深層学習アーキテクチャを用いる.

\section{2-2-1. SRCNN}

SRCNN (Super-Resolution Convolutional Neural Network) (第 2 図) は, 畳み込みフィルタによる特徴抽出を繰り返し 行う, 畳み込みニューラルネットワークをシングルフレー ム超解像に適応した最初のアーキテクチャである（Dong et al., 2014). 本アーキテクチャは, Pre-upsampling SR と呼 ばれる概念に基づいており，低解像度画像から高解像度 画像を生成する際に，デー夕の解像度を上げるアップサ ンプリングをBicubic 法であらかじめ行っておき，そこか ら 3 層のCNNによって生成画像を精緻化する手法である. SRCNNの各3層の構造は，スパースモデリングによる超 解像から着想を得ており, それぞれの層が順に特徵抽出, 非線形マッピング，高解像度画像の生成の役割を果たして いる.

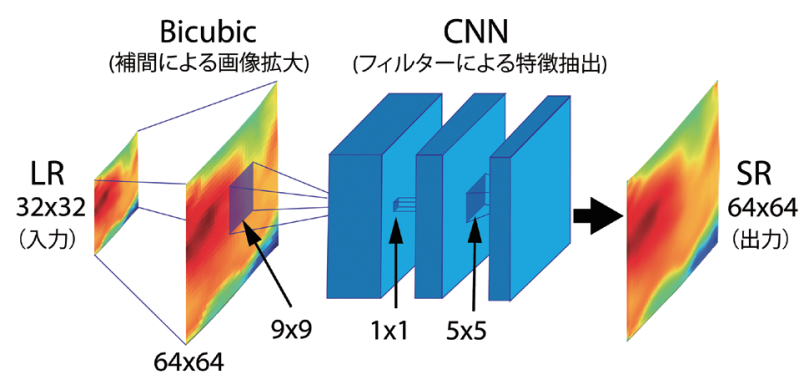

第2図 SRCNNのネットワーク構成の概要図。LR: 低解像度格子 デー夕, SR: 超解像によって得られた高解像度格子デー夕．

\section{2-2-2. FSRCNN}

FSRCNN (Fast Super-Resolution Convolutional Neural Network）(第3図）は，SRCNNの計算の複雑さを取り除 き処理スピードを大幅に改善するために提案された手法で ある (Dong et al., 2016). SRCNN が Pre-upsampling SRに 基づいているのに対し，FSRCNNは Post-upsampling SR と いうコンセプトに基づいている。一層目の畳み込み層に入 力画像を渡す前にBicubic 法で目的の解像度に画像拡大す るSRCNNでは，特徴抽出時の画像の畳み込みの際に補間 画素においても畳み込みをしているため計算のロスが多く なる，その点を考慮し，先に元の低解像画像 (LR) で特徵 抽出を行い, 最終の画像出力層の手前に逆向きの畳み込 み処理を行うことで標的解像度に画像拡大を行っている Decovolution層が配置されている，元論文では，SRCNN よりも高い精度の結果が得られたと報告されている。

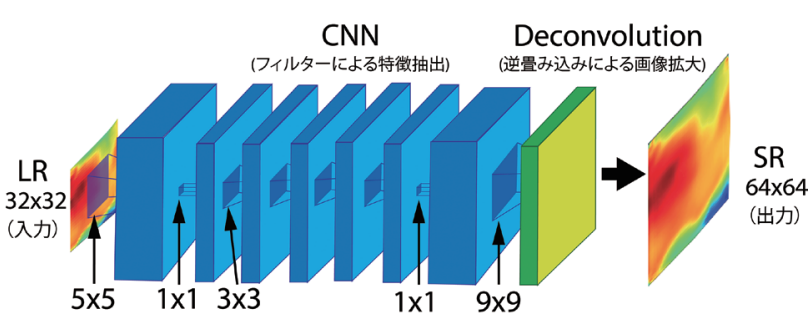

第3図 FSRCNNのネットワーク構成の概要図。LR: 低解像度格子 デー夕, SR: 超解像によって得られた高解像度格子データ。

\section{2-2-3. ESPCN}

ESPCN (Efficient sub-pixel convolutional neural network) （第4図）は，FSRCNN と同様に Post-upsampling SR をネッ トワーク構造に取り入れることで計算の高速化を図った手 法である（Shi et al., 2016）．前述の FSRCNN との大きな違 いは，ネットワークの最終層に, Deconvolution層ではな く, Sub-pixel convolution層（Pixel Shuffler）を配置してい ることである。 Deconvolution層を通して行われる画像拡 大による超解像では, チェッカーボードアーティファク 卜と呼ばれる画像の歪みが生じることが指摘されていた。 チェッカーボードアーティファクトは, 低解像度画像を逆 の畳み込みによって高解像度化する際に，入力層から引き 継いできた低解像度の特徵マップを標的解像度に揃えるた め, ゼロ埋めを行って拡大しており, フィル夕にかかる 画素の位置や数が周期的に異なることで生じる. Sub-pixel convolution 層（Pixel Shuffler）では, 低解像度の特徵マップ から標的解像度の画像を得る際，穴埋めは行わず，標的解 像度の二乗分の枚数の中間マップを用意し，各マップの画 素を順番に配置することで標的解像度の画像を生成する。 これにより，無駄な画素への畳み込み処理を削減し計算速 度が向上しただけでなく, チェッカーボードアーティファ クトの無い高い性能の超解像を実現した。

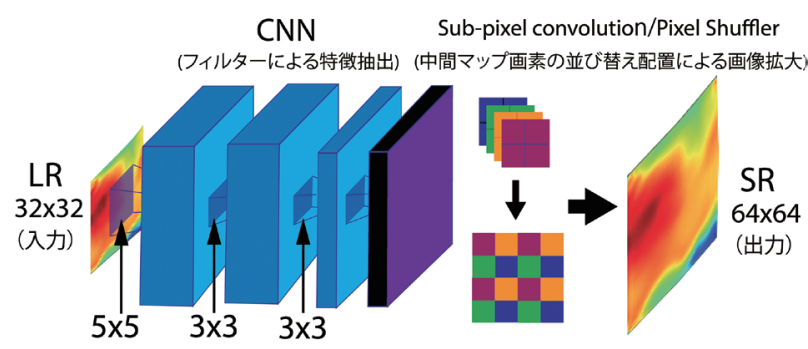

第4図 ESPCN のネットワーク構成の概要図。LR: 低解像度格子 データ, SR: 超解像によって得られた高解像度格子データ.

\section{2-2-4. SRGAN}

SRGAN (A Generative Adversarial Network for image Super-Resolution）（第5図）は, 画像生成モデルの一種で あるGAN (Generative Adversarial Network) を画像の超解 像に応用した手法である(Ledig et al., 2017)。前述まで の手法と大きく異なる点は, 生成器 (Generator) と識別器 
(Discriminator) の2つのネットワークがセットで一つの アーキテクチャとして構成されている点である. 生成器で は，LRとHRのペアを学習させ，LRからHRに近い画像 を生成できるようモデルをトレーニングする，一方，識別 器は生成器によって生成された画像と本物の HR 画像を見 分けるようにトレーニングする，2クラス分類である。 こ の二つが，相互に損失を小さくするように学習を繰り返し 行うことで, 生成器の出力值はより正解の HR 画像に近く なる。

生成器は, He et al. (2016) で提案された, Residual Network (ResNet) と呼ばれるアーキテクチャを基本構造としてお り, 他のネットワークに比べ深い層構成となっている. 理 論的には, 深層学習では層が深くなればなる程, 細部の特 徵抽出が可能になると考えられる一方で, 層が深くなるに 従い, 予測結果と正解との誤差を各層に遡ってフィード バックする際の誤差值が消失してしまう勾配消失が生じ る. ResNetでは, これに対応するため, 手前の入力層の 值をいくつかの層をスキップして伝達し，スキップした いくつかの層を経て得られた計算結果と足し合わせる Skip connection を採用している。ささらに, 生成器の末端付近に, ESPCN と同様, Sub-pixel convolution層を配置している. これらの改善によって, 画像全体の平均画像解像度を上げ る前述までの3つのアーキテクチャとは異なり, 画像内の ランダム性の高さや高周波成分の多い画像を復元すること に成功した手法である。これにより，人間が目で見て良い 画像と認識することができる, 鮮明で知覚品質の高い画像 生成を実現した。

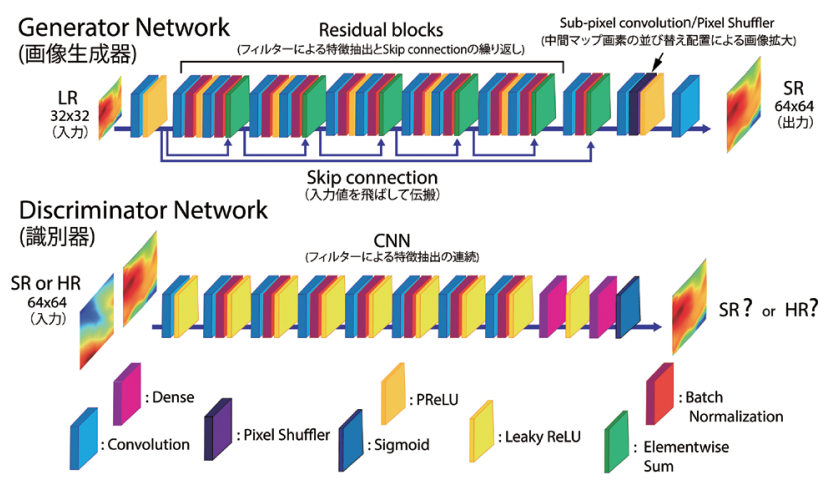

第5図 SRGANの Generator（生成器）およびDiscriminator（識別 器) のネットワーク構成の概要図. LR: 低解像度格子デー 夕, SR: 超解像によって得られた高解像度格子データ, HR: 正解の高解像度格子データ, Dense: 画像データを一 つに結合する層, Convolution: フィルタによる特徵抽出, PReLU · Sigmoid $\cdot$ Leaky ReLU: それぞれ活性化関数（活 性化関数：ネットワークの表現を向上するための非線形 変換関数), Batch Normalization: ネットワークの学習プ ロセスを全体的に安定化させる効果をもつ, Elementwise Sum: 行列の要素ごとの和.

\section{2-2-5. ESRGAN}

ESRGAN (Enhanced Super-Resolution Generative Adversarial Networks）は, 前述のSRGANを基本構成とし, 生成器 (Generator)（第6図）および識別器 (Discriminator) にそれぞれ改変を加えることで高い画像生成能力を実現 したアーキテクチャである (Wang et al., 2019). 生成器に おける変更点は, ネットワークの学習プロセスを全体的 に安定化させる効果をもつ Batch Normalization (Ioffe and Szegedy, 2015）を取り除くことによってモデルの表現力を 向上させた点, 各層の出力值を全ての層の入力として加え るDense Blockを導入した点などである。また, 識別器で は，生成された画像と本物の HR 画像を見分けるのではな く，与えられた画像の本物らしさと偽物らしさの度合いを 判断することを学習する Relativistic Discriminator (RaGAN) (Jolicoeur-Martineau, 2019) を採用している. これらの変 更により，SRGANよりもより高い知覚品質を実現した。

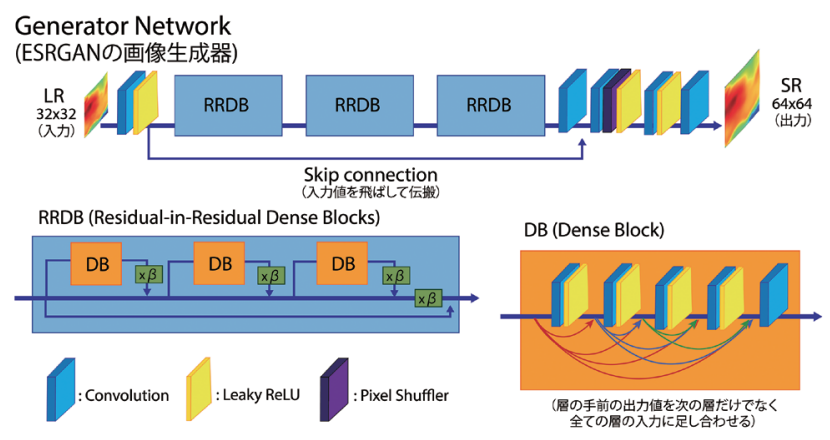

第6 図 ESRGANの Generator (生成器) のネットワーク構成の概要 図. LR: 低解像度格子デー夕, SR: 超解像によって得られ た高解像度格子デー夕, HR: 正解の高解像度格子デー夕。

\section{2-3. 性能評価指標}

超解像における学習の成否やモデルの性能は, 高解像度 化された出力結果が対応する正解画像にどのくらい近い かを指標化することで評価することができる，超解像で 最もよく用いられる評価指標はPSNR（ピーク信号対雑音 比）であるが，これには，画像全体に少しずつ差異が生じ ている場合と, 局所的に大きな差異が生じているような画 像の構造の違いを正しく評価できないという欠点がある. したがって, 本研究では, 機械学習で全般的に用いられる RMSE (二乗平均平方根誤差), 機械学習の中でも超解像 で最もよく用いられるPSNR, および画像の視覚的および 構造的な非類似性を評価する指標である DSSIM (Structural Dissimilarity）の3指標について評価を行った. 各指標の概 念を以下に示す.

\section{2-3-1. RMSE}

RMSE (二乗平均平方根誤差) は, 各画素における実際 の值と予測值の誤差の2乗を画像全体で平均したMSEの 平方根をとったものである。MSEおよびRMSEを，それ 
ぞれ式(1)および(2)に示す，RMSEが小さければ小さいほと 機械学習モデルの性能が良いと判断できる.

$$
\begin{gathered}
M S E=\frac{1}{m n} \sum_{i=1}^{m} \sum_{j=1}^{n}\left(x_{i, j}-y_{i, j}\right)^{2} \\
R M S E=\sqrt{M S E}
\end{gathered}
$$

ここで, $(i, j)$ は画素位置, $(m, n)$ は画像サイズ, $x$ は予測画 像, $y$ は正解画像である。

\section{2-3-2. PSNR}

PSNR (ピーク信号対雑音比) は, 超解像で最も広く用い られている評価指標であり式(3)で求められ，值が大きいほ ど良い評価となる。

$$
P S N R=10 \cdot \log _{10} \frac{M A X_{I}^{2}}{M S E}
$$

ここで, MAXIは画素值の取りうる最大の值である。本研 究では，画素值を0〜1の範囲に正規化しており， MAX $=$ 1である.PSNRは画像全体の画質を評価するのに適してい る指標である一方，局所的に大きな差異が生じているよう な場合の違いを正しく評価できないという欠点がある.

\section{2-3-3. DSSIM}

DSSIM (Structural Dissimilarity) は，評価対象の画像に対 し, 小領域 (window) ごとの平均・標準偏差・共分散を用 いることで, 予測画像 $x$ と正解画像 $y$ の非類似度を評価す る指標であり, 式(4)と(5)によって求められる。これにより, PSNR では評価することができなかった，画像の視覚的お よび構造的な非類似性を評価することができる，本指標に おいては，值が0に近づくほど高い評価となる。

$$
\begin{gathered}
\operatorname{SSIM}=\frac{1}{m n} \sum_{i=1}^{m} \sum_{j=1}^{n} \frac{\left(2 \mu_{x} \mu_{y}+c_{1}\right)\left(2 \sigma_{x y}+c_{2}\right)}{\left(\mu_{x}^{2}+\mu_{y}^{2}+c_{1}\right)\left(\sigma_{x}^{2}+\sigma_{y}^{2}+c_{2}\right)} \\
D S S I M=\frac{1-\operatorname{SSIM}}{2}
\end{gathered}
$$

ここで, $(i, j)$ は画素位置, $(m, n)$ は画像サイズ, $\mu_{x}$ は予測 画像 $x$ の画素 $(i, j)$ を中心とした小領域内の平均, $\mu_{y}$ は正解 画像 $y$ の画素 $(i, j)$ を中心とした小領域内の平均, $\sigma_{x}^{2}$ は予 測画像 $x$ の画素 $(i, j)$ を中とした小領域内の分散, $\sigma_{x y}$ は 画素 $(i, j)$ を中心とした小領域内の共分散, $c_{1}$ と $c_{2}$ は係数 である. 小領域サイズ $=11 \times 11, c_{1}=0.01, c_{2}=0.03$ は, Wang et al. (2004) を踏襲したものである.

\section{3. 結果と考察}

本研究では, 2-1.に示した学習データを用い, SRCNN, FSRCNN, ESPCN, SRGAN, ESRGANの $5 つ$ 超解像 モデルの学習を行い, テストデータを適用した結果と Bicubic 法による結果の比較と検証を行った。全テスト結 果のRMSE，PSNR, DSSIMの平均值を第1表に示し, 全 テストデータのうちランダムに選んだ場所の異なる6つの 領域について, 入力データ (LR), Bicubicによる補間, 5 つのモデルによる超解像結果および正解デー夕 (HR) を第 7 図に示した。第7図は, 小領域ごとに超解像結果を評価 する都合上, 水深データに対して便宜的に疑似カラーを割 り当てることで画像化している，疑似的な色表現として， 各小領域における高解像度データの最小值から最大值に対 し，青から赤に変化するよう色相を設定した．全テストの 結果の平均から, FSRCNNのPSNR 值を除き, 全ての結果 がBicubic 法の結果を上回った。領域ごとの結果を見ると， ばらつきがあり，各モデルによる精度の順位はかならずし も平均值による結果と一致しないことがわかる.

第7図の上から 3 列目から5列目の結果は, 領域内の高 低差が100-200 m 程度の事例である。いずれのモデルに よる結果においても，ほとんどの事例においてPSNR お よびDSSIMともにBicubic と比べて同程度以上（Bicubicに

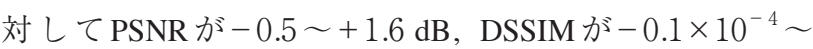
$\left.-1.0 \times 10^{-5}\right)$ の数值が得られている. 特に地形の起伏が 比較的少ない 3 列目および4列目の事例では, PSNRおよ びDSSIM ともにSRCNN（Bicubicに対してPSNRが+1.6 $\mathrm{dB}$ と $+0.3 \mathrm{~dB}, \quad$ DSSIMがー $0.9 \times 10^{-5}$ と $\left.-0.3 \times 10^{-5}\right)$ およ びESPCN（Bicubicに対してPSNRが+1.1 dB と $-0.3 \mathrm{~dB}$, DSSIMが $-1.0 \times 10^{-5}$ と $\left.-0.5 \times 10^{-5}\right)$ の精度が高くなって いる. また, $300 \mathrm{~m}$ 程度の起伏が多く見られる 2 列目の事 例については，アーティファクトの少ないモデルである ESPCN（Bicubicに対してPSNRが+0.8 dB，DSSIMが-0.3 $\left.\times 10^{-3}\right)$ や，画像内のランダム性の高さや高周波成分の 多い画像を復元することに特化したGAN系モデル（特に ESRGANは，Bicubicに対してPSNRが+1.7 dB，DSSIM が- $\left.0.5 \times 10^{-3}\right)$ の精度の高さが目立つ。一方，1列目お よび 6 列目は，高低差が $20 \mathrm{~m}$ 程度の事例である。両事例 ともに，各モデルの結果はBicubic と比較して同程度ま たはそれ以下（Bicubicに対してPSNRが-0.5〜+1.0 dB， DSSIMが $\left.-0.1 \times 10^{-5} \sim+0.5 \times 10^{-5}\right)$ であり，精度の向上 が見られない.また, 1列目のSRGANによる結果を見ると， 領域の外側から数画素目あたりに高周波のノイズが直列し

第 1 表 各手法に扔ける各評価指標の結果 (テストデー夕全量の平均值, $\mathrm{N}$ 值 $=2731$ ). e を含む数值は浮動小数点表記を示す.

\begin{tabular}{ccccccc}
\hline & Bicubic & SRCNN & FSRCNN & ESPCN & SRGAN & ESRGAN \\
\hline RMSE $(\mathrm{m})$ & 1.47 & 1.32 & 1.45 & 1.31 & 1.36 & 1.26 \\
PSNR $(\mathrm{dB})$ & 66.32 & 67.18 & 66.30 & 67.18 & 66.64 & 67.24 \\
DSSIM & $2.03 \mathrm{e}-04$ & $1.64 \mathrm{e}-04$ & $1.80 \mathrm{e}-04$ & $1.58 \mathrm{e}-04$ & $1.61 \mathrm{e}-04$ & $1.44 \mathrm{e}-04$ \\
\hline
\end{tabular}




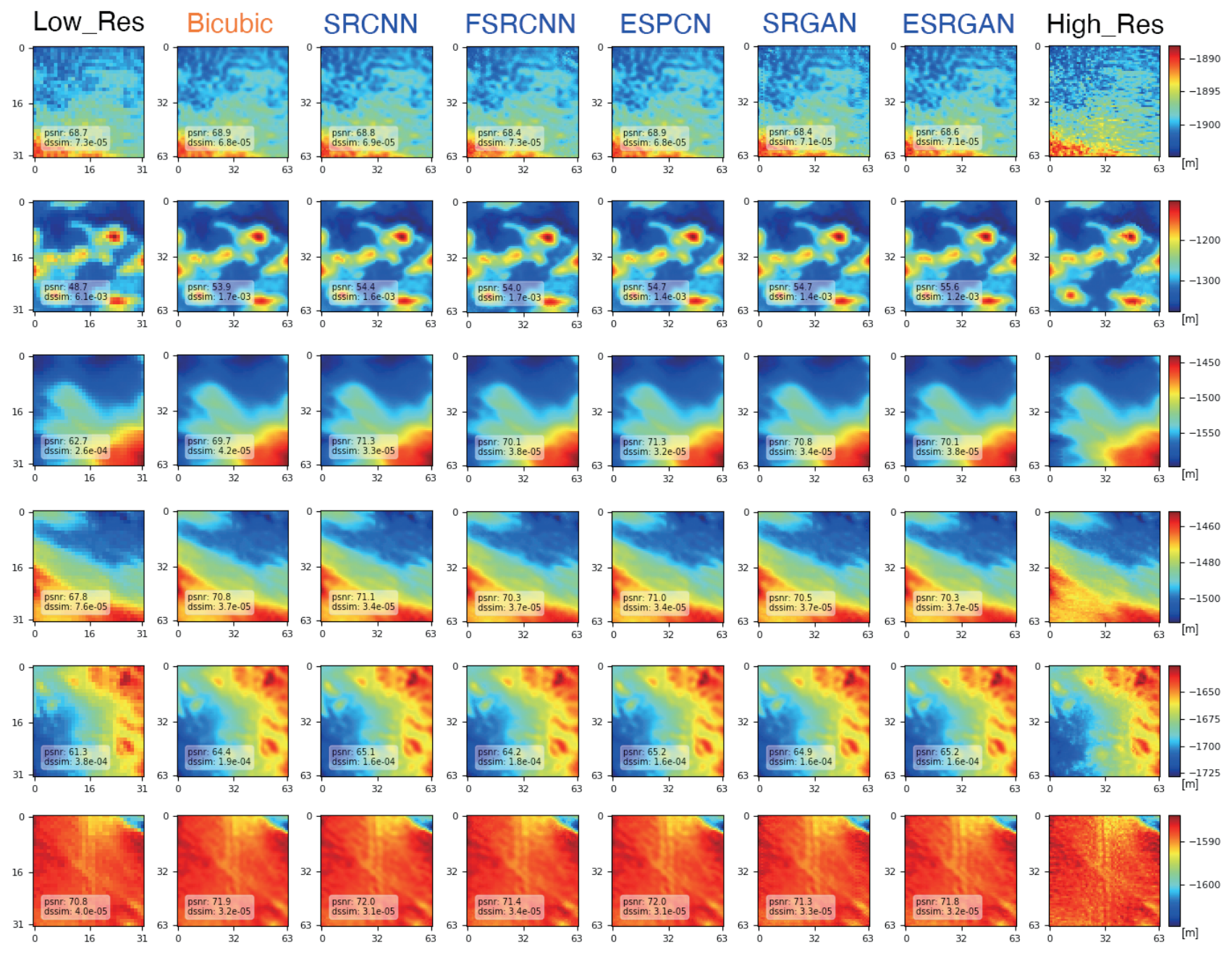

第7図 入力デー夕(低解像度), 正解デー夕 (高解像度) および各手法によって得られた超解像結果比較. e を含む数值は浮動小数点表記を示す.

ているのが見え, 精度低下の一因となっていることが考え られる。 GANによる超解像では, 入力画像とは無関係に 高周波ノイズを生成する傾向にあることも報告されている (Park et al., 2018).

参考までに，第7図における予測值と正解值の差分を第 8 図に示す.この結果からも, 起伏の大きい2列目の例に おいて, ESRGANが良い結果を示していることが確認で きる。また, GAN系の手法は, 他の手法と比較すると真 值より低婎定していることを示す青色が多い. 第 8 図 により，第7図ではわからなかった地形とは無関係の斜線 状の構造が確認されるが, これは計測データをグリッド データに変換したときの欠損值によるアーティファクトに よるものと考えられる

第 9 図 (d) - (e) では, 局所的な起伏の量を示す特徵量と して傾斜量を用い, 適当な範囲の傾斜量毎に精度を示し ている. 0〜1の範囲に正規化された正解值を用いて画素 単位での傾斜量を算出し, 領域内での傾斜量の平均值を 各テストデータの特徴量としている。傾斜量の計算には
沖村ほか（1991）による手法を用いた。 中央值を見ると， RMSE，PSNR およびDSSIMの值は各モデルともにBicubic と比べても大きな違いはない. 第三四分位数 (RMSEおよ びDSSIM）または第一四分位数（PSNR）を見ると，ほとん どの場合において Bicubicよりも同等以上の精度を示して いる。特にSRCNN, ESPCNおよびESRGANは, RMSE, PSNR, DSSIM ともに著しく悪い結果が出にくく, 安定し たモデルであると言える。特に注目すべき点は，画像中の 起伏が比較的大きいことを示す傾斜量が 0.1 以上の場合で ある.PSNRを見ると，SRGANおよびESRGANによる結 果 (第三四分位) は他モデルと比較しても同程度であるが, 画像の鮮明さを適切に評価する指標であるDSSIMを見る と, 特に精度のばらつきが小さいことが分かる。これは, 鮮明さを重視する GAN 系ならではの特徴が表れていると 言える.

本研究の, $100 \mathrm{~m}$ メッュの格子データから $50 \mathrm{~m}$ メッ シュの格子データを生成する超解像夕スクにおいて, 画 像拡大にDeconvolution層を採用したFSRCNNを除き, そ 
Bicubic

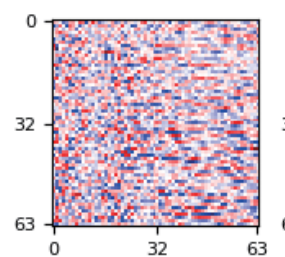

\section{SRCNN}

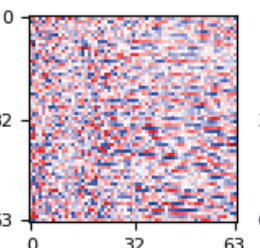

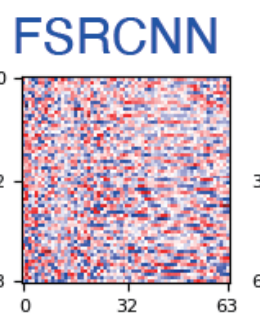
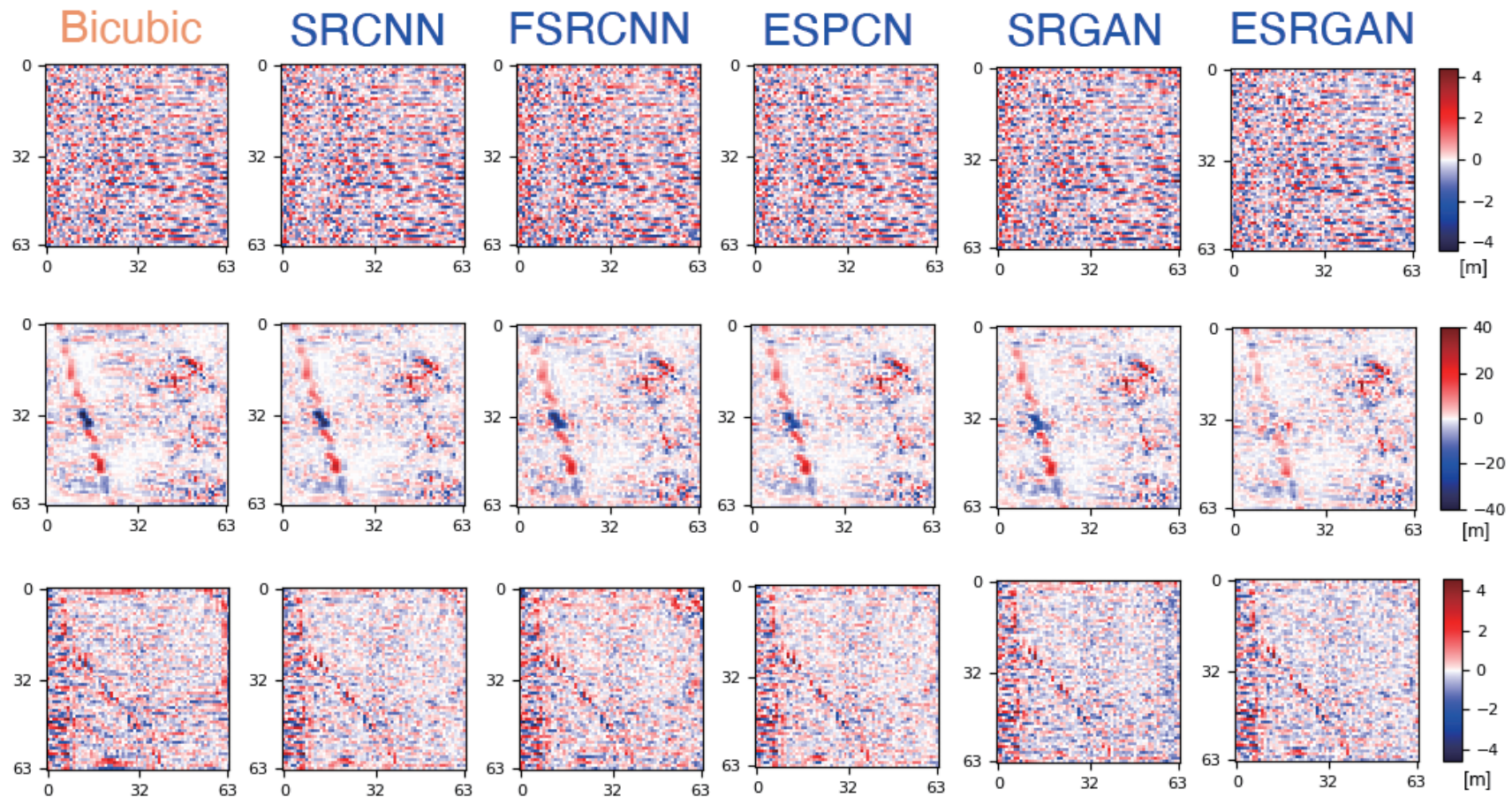
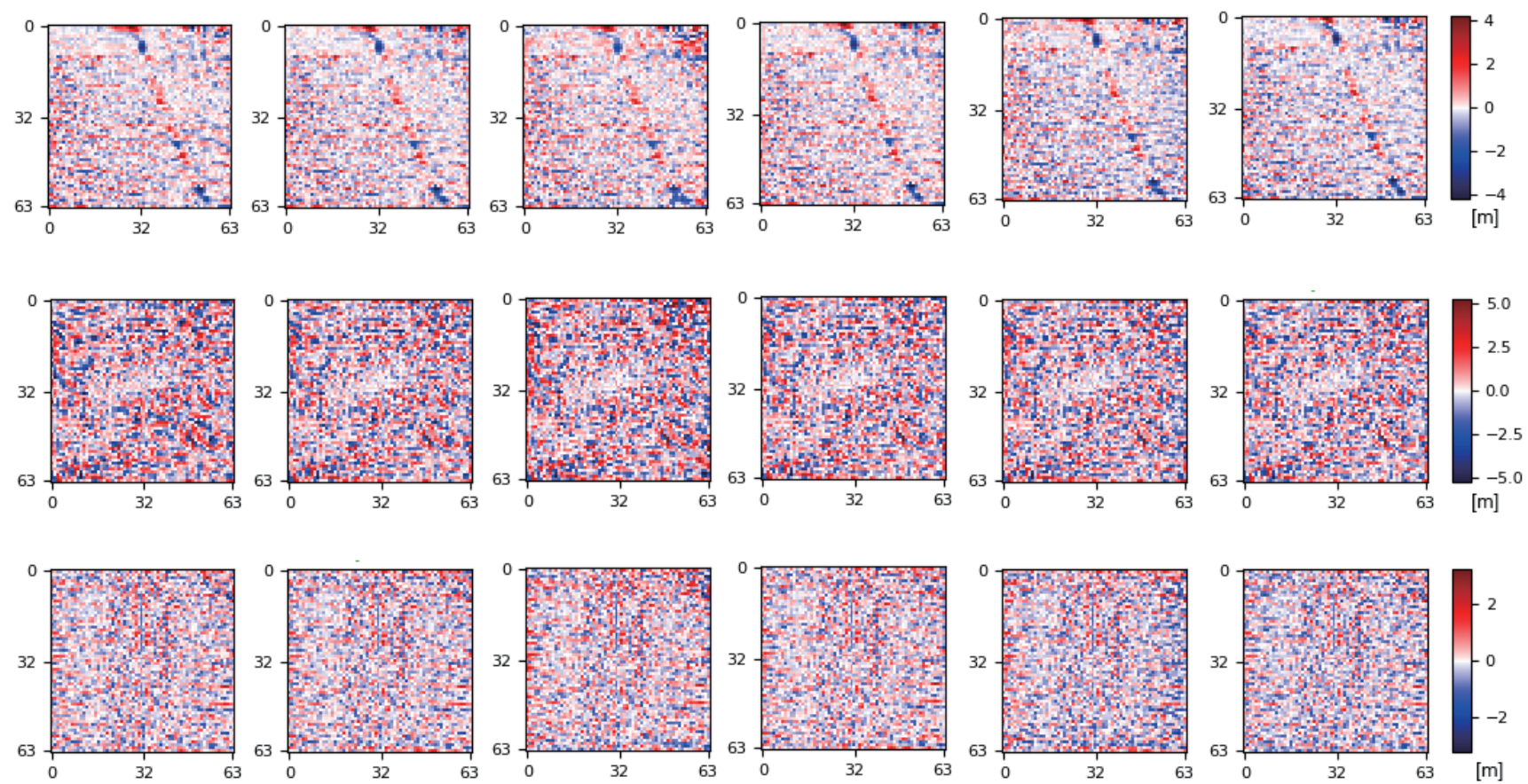

第8図 正解と各手法の推定結果との差分. 各結果は, 第7図の順番に対応. 赤いほど真值より高めに推定, 青いほど低めに推定.

れぞれのモデルが各評価指標でBicubic 法を上回る結果と なった. 全体の平均的な, 精度を見るだけでは分からなかっ たが，領域ごとの結果を見ることで手法によって精度が異 なることが明らかとなった。例えば，画像領域内の起伏が 少ないケースではSRCNN と ESPCNが優れており, 起伏が 極めて激しい場合はESPCN とESRGANが優れている。ま た，起伏が極めて少ないケースではBicubicでも十分であ るなど，各手法と地形的特徴との間に何らかの傾向が存在
していることが示唆された. さらに, 領域内の高低差や傾 斜量と各モデルの精度のばらつきについて検証した結果, SRCNN，ESPCNおよびESRGANが極めて安定した手法で あることが明らかになった。これらの結果を受け，一つの 優れたモデルを選定する場合, 手法の安定性と領域内の起 伏に対する適応性の観点からすると，ESPCNは優れた手 法であると考えられる，一方，地形的条件によって水深勾 配の異なる海底地形においては, 対象の領域によってモデ 

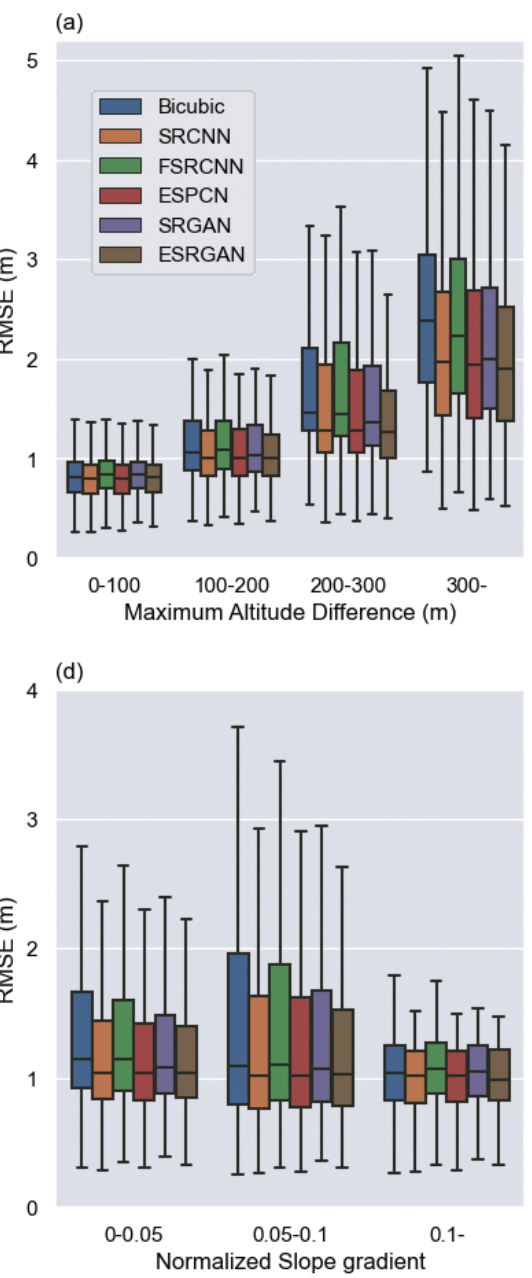

(b)

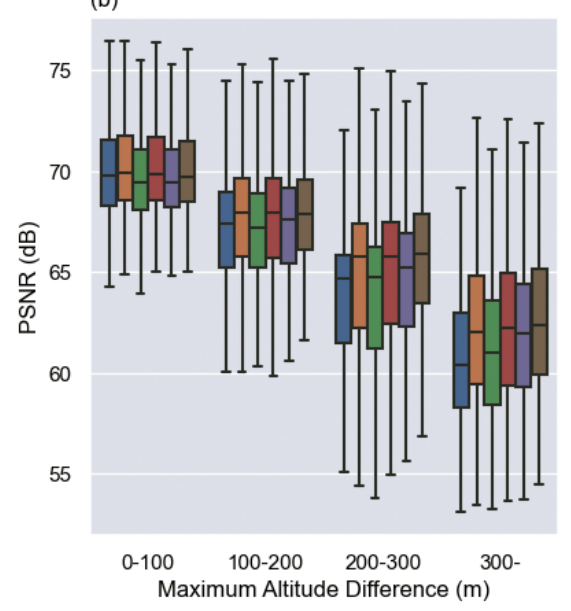

(e)

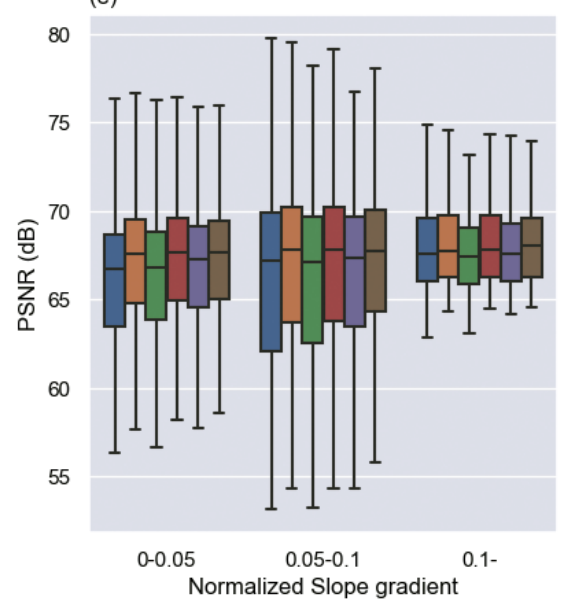

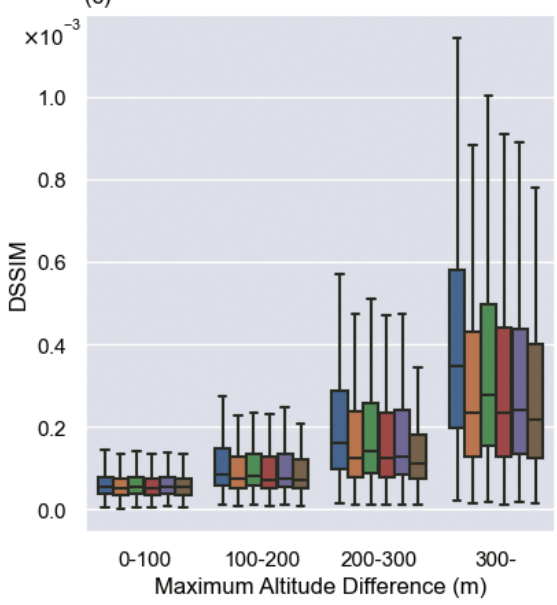

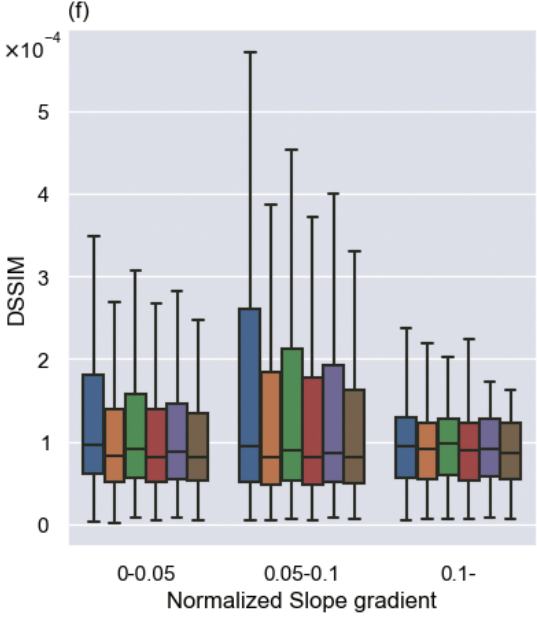

第 9 図 全テストデータに対する (a)-(c) 最大水深差, (d)-(f) 傾斜量毎の超解像精度の比較.

ルを使い分ける必要があると考えられる。例えば，極めて 激しい起伏がある地形ではESRGANを用いた方が良い場 合や，高低差の乏しい地形では深層学習を用いなくても Bicubic 法で十分な場合がある。

\section{4. まとめ}

本研究では, マルチビーム測深機で取得したデータから 作成された海底地形データに, 代表的な深層学習超解像 アーキテクチャでモデルを作成し超解像を行なった。その 結果, ほとんどの場合において, 各深層学習モデルによる 超解像結果はBicubicによる結果を上回ることを確認した. また, 平均的にはESRGANやESPCN の性能が高いという 結果が得られた。一方, 各モデルでは, 対象領域の傾斜量 や勾配差等の地形的特徵によって精度が異なり, それらは 用いる評価指標によっても異なる場合があった，本研究に よる結果は, 超解像を行いたい領域の地形的特徴によって 最も適した超解像モデルおよび評価指標の組み合わせを選 択することが望ましいことを示唆している.
深層学習を用いた超解像は, 一般に, 大量のデータから 学習される多くの特徵量によって精度の向上を眓ろうとす るものである, 一方で, 情報地質分野においては, 前述し た通り地形学的または地球統計学的な情報を取り入れた手 法が1960年代から研究されてきた。 これらの知見を深層 学習に取り入れることによって, さらなる発展が見込める ものと思われる.

謝辞：本研究は, 海洋調査船「みらい」,「なつしま」,「よ こすか」の調査航海 MR13-E02, MR15-E01, NT13-22, NT15-02, YK13-14, YK14-17，YK15-06において実施さ れた地形観測データによる成果です。各船の船長をはじめ とし, 乗組員の皆様, 同航海で技術支援をいただいた皆様 に心より御礼申し上げます。最後に, 本原稿を注意深くお 読みいただき, 適切なご助言を頂きました匿名の査読者に 感謝申し上げます。 


\section{文献}

Briggs, I. C. (1974) Machine contouring using minimum curvature. Geophysics, vol. 39, no. 1, pp. 39-48.

https://doi.org/10.1190/1.1440410

Chilès, J.-P. and Delfiner, P. (2012) Geostatistics: Modeling Spatial Uncertainty $2^{\text {nd }}$ Edition. Wiley, New York, 734 p. ISBN: 978-0-470-18315-1

DeSET (2020) PROJECT OUTLINE: プロジェクト概要. 株 式会社リバネス. https://deset.lne.st/project/

Deutsch, C. V. and Journel, A. G. (1998) GSLIB Geostatistical Software Library and User's Guide $2^{\text {nd }}$ edition. Oxford University Press, New York, 369 p.

ISBN-13 : 978-0195073928

Dong, C., Loy, C. C., He, K. and Tang, X. (2014) Learning a deep convolutional network for image super-resolution. In: Fleet, D., Pajdla, T., Schiele, B. and Tuytelaars, T. (eds) Computer Vision - ECCV 2014. ECCV 2014. Lecture Notes in Computer Science, Springer, Cham, vol. 8692, pp. 184-199. https://doi.org/10.1007/978-3-319-10593-2_13

Dong, C., Loy, C. C., and Tang, X. (2016) Accelerating the super-resolution convolutional neural network. In: Leibe, B., Matas, J., Sebe, N. and Welling, M.(eds) Computer Vision ECCV 2016. ECCV 2016. Lecture Notes in Computer Science, Springer, Cham, vol. 9906, pp. 391-407. https://doi.org/10.1007/978-3-319-46475-6_25

Goodfellow, I. J., Pouget-Abadie, J., Mirza, M., Xu, B., WardeFarley, D., Ozair, S., Courville, A. and Bengio, Y. (2014) Generative adversarial nets. In: Proceedings of the $27^{\text {th }}$ International Conference on Neural Information Processing Systems (NIPS), Montreal, Canada, vol. 2, pp. 2672-2680. https://dl.acm.org/doi/10.5555/2969033.2969125

He, K., Zhang, X., Ren, S. and Sun, J. (2016) Deep residual learning for image recognition. In: IEEE Conference on Computer Vision and Pattern Recognition (CVPR), Las Vegas, NV, USA, pp. 770-778.

https://doi.org/10.1109/CVPR.2016.90

Hinton, G. E. and Salakhutdinov, R. R. (2006) Reducing the dimensionality of data with neural networks. Science, vol. 313, no. 5786, pp. 504-507.

https://doi.org/10.1126/science.1127647

井上 公 (1985) 一般化インバース理論に基づく離散データ の平滑化. 情報地質, no. 10,pp. 105-134. https://doi.org/10.6010/geoinformatics1975.1985.10_105

Ioffe, S . and Szegedy, C. (2015) Batch normalization: accelerating deep network training by reducing internal covariate shift. In: Proceedings of the $32^{\text {nd }}$ International Conference on International Conference on Machine Learning (ICML), Lille, France, vol. 37, pp. 448-456. https://dl.acm.org/doi/10.5555/3045118.3045167
伊藤喜代志（2019）機械学習による超解像技術を活用した 詳細な深海海底地形図の作成. 水産工学, vol. 56, no. 1 , pp. 47-50. https://doi.org/10.18903/fisheng.56.1_47

Jolicoeur-Martineau, A. (2019) The relativistic discriminator: a key element missing from standard GAN. International Conference on Learning Representations (ICLR), Montreal, Canada. https://openreview.net/pdf?id=S1erHoR5t7

木戸ゆかり (2020) JAMSTEC の新研究プログラム“数理海 底地形科学”始動。情報地質, vol. 31, no. 1, pp. 13-15.

https://doi.org/10.6010/geoinformatics.31.1_13

Koike, K., Matsuda, S., Suzuki, T. and Ohmi, M. (2002) Neural network-based estimation of principal metal contents in the Hokuroku District, northern Japan, for exploring kuroko-type deposits. Natural Resources Research, vol. 11, no. 2, pp. 135156. https://doi.org/10.1023/A:1015520204066

Koike, K. and Matsuda, S. (2003) Characterizing content distributions of impurities in a limestone mine using a feedforward neural network. Natural Resources Research, vol. 12, no. 3, pp. 209-222. https://doi.org/10.1023/A:1025180005454

Krizhevsky, A., Sutskever, I. and Hinton, G. E. (2012) ImageNet classification with deep convolutional neural networks. In: Proceedings of the $25^{\text {th }}$ International Conference on Neural Information Processing Systems (NIPS), Lake Tahoe, Nevada, vol. 2, pp. 1097-1105.

https://dl.acm.org/doi/10.5555/2999134.2999257

笠谷貴史・金子純二 ·岩本久則（2020）音響調査と自然電 位法を用いた海底熱水鉱床調査技術プロトコルに基づく 調査とその検証. 物理探査, vol. 73,pp. 42-52 https://doi.org/10.3124/segj.73.42

Lecun, Y., Bottou, L., Bengio, Y. and Haffner, P. (1998) Gradient-based learning applied to document recognition. In: Proceedings of the IEEE, vol. 86, no. 11, pp. 2278-2324. https://doi.org/10.1109/5.726791

Ledig, C., Theis, L., Huszár, F., Caballero, J., Cunningham, A., Acosta, A., Aitken, A., Tejani, A., Totz, J., Wang, Z. and Shi, W. (2017) Photo-realistic single image super-resolution using a generative adversarial network. In: IEEE Conference on Computer Vision and Pattern Recognition (CVPR), Honolulu, HI, pp. 105-114. https://doi.org/10.1109/CVPR.2017.19

Mayer, L., Jakobsson, M., Allen, G., Dorschel, B., Falconer, R., Ferrini, V., Lamarche, G., Snaith, H. and Weatherall, P. (2018) The Nippon Foundation - GEBCO Seabed 2030 Project: The Quest to see the world's oceans completely mapped by 2030 . Geosciences, vol. 8, no. 2, p. 63. https://doi.org/10.3390/geosciences8020063

Nock, K., Bonanno, D., Elmore, P., Smith, L., Ferrini, V. and Petry, F. (2019) Applying single-image super-resolution for the enhancement of deep-water bathymetry. Heliyon, vol. 5 , 
no. 10, e02570. https://doi.org/10.1016/j.heliyon.2019.e02570 野々垣 進・升本眞二・塩野清治 (2008) 3 次 B-スプラインを 用いた地層境界面の推定. 情報地質, vol. 19, no. 2, pp. 6177. https://doi.org/10.6010/geoinformatics.19.61 沖村 孝・吉永秀一郎・鳥井良一 (1991) 地形特性值と地形区 分, 表土層厚の関係一仙台入菅谷地区を例として一。神 戸大学土地造成工学研究施設報告, vol. 9, pp. 19-39.

Park, S-J., Son, H., Cho, S., Hong, K-S. and Lee, S. (2018) SRFeat: Single image super resolution with feature discrimination. In: Ferrari, V., Hebert, M., Sminchisescu, C. and Weiss, Y. (eds) Computer Vision - ECCV 2018. ECCV 2018 Lecture Notes in Computer Science, vol. 11220, pp. 455471. https://doi.org/10.1007/978-3-030-01270-0_27

Shi, W., Caballero, J., Huszár, F., Totz, J., Aitken, A. P., Bishop, R., Rueckert, D. and Wang, Z (2016) Real-time single image and video super-resolution using an efficient subpixel convolutional neural network. In: IEEE Conference on Computer Vision and Pattern Recognition (CVPR), Las Vegas, NV, USA, pp. 1874-1883.

https://doi.org/10.1109/CVPR.2016.207

Sonogashira, M., Shonai, M. and Iiyama, M. (2020) Highresolution bathymetry by deep-learning-based image superresolution. PLOS ONE, vol. 15, no. 7, e0235487. https://doi.org/10.1371/journal.pone.0235487
Wang, Z., Bovik, A. C., Sheikh, H. R. and Simoncelli, E. P. (2004) Image quality assessment: from error visibility to structural similarity. IEEE Transactions on Image Processing, vol. 13, no. 4, pp. 600-612. https://doi.org/10.1109/TIP.2003.819861

Wang, X., Yu, K., Wu, S., Gu, J., Liu, Y., Dong, C., Qiao, Y. and Loy, C. C. (2019) ESRGAN: Enhanced Super-Resolution Generative Adversarial Networks. In: Leal-Taixé, L. and Roth, S. (eds) Computer Vision - ECCV 2018 Workshops. ECCV 2018. Lecture Notes in Computer Science, Springer, Cham, vol. 11133, pp. 63-79. https://doi.org/10.1007/978-3-030-11021-5_5

Yang, J., Wright, J., Huang, T. and Ma, Y. (2008) Image superresolution as sparse representation of raw image patches. In: IEEE Conference on Computer Vision and Pattern Recognition (CVPR), Anchorage, AK, USA, pp. 1-8. https://doi.org/10.1109/CVPR.2008.4587647

Yang, J., Wright, J., Huang, T. S. and Ma, Y. (2010) Image superresolution via sparse representation. IEEE Transactions on Image Processing, vol. 19, no. 11, pp. 2861-2873. https://doi.org/10.1109/TIP.2010.2050625

横矢直和・山本和彦・舟久保登 (1987) フラクタルによる3 次元自然形状の解析とその地形モデル作成への応用. 電 子情報通信学会論文誌 D, vol. J70-D, no.12, pp. 2605-2614.

3 ）国立研究開発法人海洋研究開発機構 海域地震火山部門 ₹ 237-0061 神奈川県横須賀市夏島町 2-15.

Research Institute for Marine Geodynamics (IMG), Japan Agency for Marine-Earth Science and Technology (JAMSTEC), 2-15 Natsushima-cho, Yokosuka, Kanagawa 237-0061, Japan. E-mail: kuwatani@ jamstec.go.jp

4) 国立研究開発法人海洋研究開発機構 海洋機能利用部門 ₹ 237-0061 神奈川県横須賀市夏島町 2-15.

Research Institute for Marine Resources Utilization, Japan Agency for Marine-Earth Science and Technology (JAMSTEC), 2-15 Natsushima-cho, Yokosuka, Kanagawa 237-0061, Japan. E-mail: kanekoj@jamstec.go.jp

5 ）国立研究開発法人海洋研究開発機構 海洋機能利用部門. Research Institute for Marine Resources Utilization, Japan Agency for Marine-Earth Science and Technology (JAMSTEC).E-mail: tkasa@jamstec.go.jp

6) 国立研究開発法人海洋研究開発機構 研究プラットフォーム運用開発部門 § 237-0061神奈川県横須賀市夏島町 2-15. Institute for Marine-Earth Exploration and Engineering (MarE3), Japan Agency for Marine-Earth Science and Technology (JAMSTEC), 2-15 Natsushima-cho, Yokosuka, Kanagawa 237-0061, Japan. E-mail: ykido@ jamstec.go.jp

7) 国立研究開発法人海洋研究開発機構 付加価值情報創生部門. Research Institute for Value-Added-Information Generation (VAiG), Japan Agency for Marine-Earth Science and Technology (JAMSTEC). E-mail: ishikaway@jamstec.go.jp

8 ）国立研究開発法人海洋研究開発機構 付加価值情報創生部門. Research Institute for Value-Added-Information Generation (VAiG), Japan Agency for Marine-Earth Science and Technology (JAMSTEC). E-mail: kikawa@jamstec.go.jp いであ株式会社国土環境研究所 ₹ 224-0025 神奈川県横浜市都筑区早㴊 2-2-2. IDEA Consultants, Inc., 2-2-2 Hayabuchi, Tsuzuki-ku, Yokohama, Kanagawa 224-0025, Japan. 
要 旨

\section{深層学習による海底地形図超解像の手法比較と検証}

日高弥子・松岡 大祐・桑谷立・金子 純二 笠谷貴史・木戸ゆかり・石川洋一・木川 栄一

海底地形情報はあらゆる分野において重要な基本情報である，特に，解像度の高い海底地形情報は需要が高まっ ており, 近年では, 全球的に高解像度の海底地形情報を取得しようとする取り組みが活発になっている。我々は, 既に存在している低解像度の海底地形図を深層学習による超解像手法で高解像度化することの有効性について検証 することで, 課題解決に貢献できるのではないかと考えた。本研究では, 自然画像の超解像に対し, 既に高い精度 で高解像度化に成功している5つの深層学習アーキテクチャで, $100 \mathrm{~m}$ 格子の海底地形図から $50 \mathrm{~m}$ 格子の海底地形図 に高解像度化するモデルを作成し, 各手法による結果の比較検証を行った。 その結果, 各手法では, 地形図領域内 の水深勾配によって精度が異なり, 高解像度化を行いたい海底地形図の領域によって異なる手法を用いる方が良い 場合があることが示唆された.

キーワード：海底地形, 超解像, 機械学習, 深層畳み込みニューラルネットワーク, 画像処理 